\title{
Acute cholecystitis in neutropenic patients
}

\author{
Uriel Clemente-Gutiérrez, German Esteban Sánchez Morales, Paulina Moctezuma Velazquez, \\ Alexandra Rueda de León Aguirre, Jesus Morales Maza, Ismael Dominguez-Rosado, \\ and Heriberto Medina-Franco
}

Department of Surgery, National Institute of Health Sciences and Nutrition Salvador Zubirán, Mexico City, Mexico

\begin{abstract}
Backgrounds/Aims: The frequency of acute cholecystitis reported in neutropenic patients is between $0.4-1.65 \%$. Clinical manifestations differ from general population as well as clinical approach, diagnosis and treatment. The aim of this work is to describe clinical characteristics, diagnostic approach, and outcomes of patients with hematological diseases that presented with neutropenia and fever associated with acute cholecystitis in a tertiary referral hospital. Methods: We performed a retrospective analysis of patients with diagnosis of neutropenia and fever associated with acute cholecystitis in the period between January 2000 and January 2017. Quantitative variables were analyzed with mean and standard deviation, and qualitative variables with frequency and percentage. Results: During the study period, 2007 patients presented with neutropenia and fever. Twelve of them $(0.59 \%)$ had associated acute cholecystitis. The most common hematologic disease among these patients was lymphoblastic leukemia. Acute acalculous cholecystitis was diagnosed in 6 cases $(50 \%)$. Eleven patients $(91.6 \%)$ had a severe presentation and cholecystostomy was performed in $9(75 \%)$ cases. The main cause of mortality was septic shock (33.3\%). Conclusions: Treatment of acute cholecystitis in patients with neutropenia must be individualized. Cholecystostomy should be considered as a bridge therapy for an interval cholecystectomy. (Ann Hepatobiliary Pancreat Surg 2019;23:234-239)
\end{abstract}

Key Words: Cholecystitis; Leukemia; Neutropenia

\section{INTRODUCTION}

Abdominal infections in patients with neutropenia are usually severe and life-threatening. ${ }^{1}$ Neutropenia may be due to a primary hematologic disorder or secondary to chemotherapy. The frequency of acute cholecystitis in this population is between $0.4-1.65 \%$ with a 30 -day mortality of $26-48 \%,{ }^{2}$ being acalculous cholecystitis the most common presentation. ${ }^{3,4}$

Neutropenic enterocolitis is the most common intra abdominal infections associated with fever in neutropenic patients. ${ }^{5,6}$ However, acute cholecystitis may have an atypical presentation in this patients and should always be considered as a differential diagnosis. ${ }^{7,8}$

Unfortunately there is scarce information on this topic on the literature and as a result there are no specific recommendations to guide diagnosis and treatment of acute cholecystitis in hematologic diseases. The aim of this study was to describe the clinical characteristics, diagnostic approach, treatment, and outcomes of patients with hematological disorders, specifically neutropenia and fever associated with acute cholecystitis in a tertiary referral hospital.

\section{PATIENTS AND METHODS}

A search was performed at our institution's electronic system to identify patients admitted to the hospital with the diagnosis of neutropenia and fever between January 2000 and January 2017. We included patients with diagnosis of acute cholecystitis. Neutropenia was defined according to the American Society of Hematology as an absolute neutrophil count below 1,500 cells $/ \mu 1 .^{9}$ Diagnosis and severity of acute cholecystitis were established based

Received: July 10, 2018; Revised: November 10, 2018; Accepted: November 15, 2018

Corresponding author: Heriberto Medina-Franco

Department of Surgery, National Institute of Medical Sciences and Nutrition Salvador Zubirán, Vasco de Quiroga, 15 Col. Sección XVI. Del. Tlalpan C.P. 14000 México, D.F., México

Tel: +52-54870900, Fax: +52-55739321, E-mail: herimd@hotmail.com

Copyright (C) 2019 by The Korean Association of Hepato-Biliary-Pancreatic Surgery

This is an Open Access article distributed under the terms of the Creative Commons Attribution Non-Commercial License (http://creativecommons.org/ licenses/by-nc/4.0) which permits unrestricted non-commercial use, distribution, and reproduction in any medium, provided the original work is properly cited. Annals of Hepato-Biliary-Pancreatic Surgery • pISSN: 2508-5778 - elSSN: 2508-5859 
on the Tokyo guidelines. ${ }^{10,11}$ Quantitative variables were described with mean and standard deviation and qualitative variables with absolute frequencies and percentages.

\section{RESULTS}

\section{General characteristics}

Out of 2,007 patients hospitalized for neutropenia and fever 12 cases $(0.59 \%)$ were associated with acute cholecystitis (Table 1). The median age was 35 years $(21-70$ years old), 5 patients were women $(41.6 \%)$.

\section{Acute cholecystitis diagnosis and severity}

All patients, except one who had no abdominal pain, met diagnostic criteria for acute cholecystitis according to Tokyo 2013 criteria. Acute acalculous cholecystitis was diagnosed in 6 individuals (50\%). The most common local sign of inflammation was Murphy's sign in 7 patients (58.3\%). Regarding systemic inflammatory response, fever and tachycardia were present in 9 patients (75\%), and 5 patients $(41.6 \%)$ had elevated $\mathrm{C}$ reactive protein. $\mathrm{Ab}$ dominal ultrasound was performed in 10 patients $(91.6 \%)$, and computed tomography in 2 (16.2\%); findings were compatible with acute cholecystitis. Eleven patients (91.6\%) presented with severe acute cholecystitis. Organ failures included hematological dysfunction (platelets $<100,000 / \mathrm{mm}^{3}$ ) in 11 patients (91.6\%), cardiovascular dysfunction (hypotension requiring vasopressors) in 5 patients $(41 \%)$, renal dysfunction (creatinine $>2.0 \mathrm{mg} / \mathrm{dl}$ ) in 4 patients $(33.3 \%$ ), and respiratory dysfunction $(\mathrm{PaO} 2 / \mathrm{FiO} 2$ ratio $<300)$ in 2 patients $(16.6 \%)$ Table 2.

\section{Hematologic characteristics}

Concerning the hematologic diagnosis, seven patients (58.3\%) had lymphoblastic leukemia, and acute myeloid leukemia, non-Hodgkin lymphoma, NK lymphoma, myelodysplastic syndrome (dendritic cell neoplasia), and aplastic anemia were present 1 patient $(8.3 \%)$ each. Seven patients $(58 \%)$ were under chemotherapy with HyperCVAD (hyperfractionated cyclophosphamide, vincristine sulfate, doxorubicin hydrochloride and dexamethasone), and the others with regimens that included cytarabine/ rituximab, cyclosporine/bisulfan, or the SMILE scheme (dexamethasone, methotrexate, ifosfamide, L-asparaginase and etoposide). Regarding chemotherapy adverse effects, grade 1-2 neurotoxicity was observed in two patients (16.6\%) and grade 1-4 hematotoxicity in 11 (91.6\%). Among those patients who received Hyper-CVAD therapy, grade 3-4 neutropenia and thrombocytopenia developed in all patients, and grade 1-2 anemia in five of them (71\%).

The median time that elapsed between the last chemotherapy administration and the event of acute cholecystitis was 36.58 days (range 6-150). In preparation for cholecystostomy, 8 (88.8\%), 1 (11.1\%), and 1 (11.1\%) patients were transfused with platelets, fresh frozen plasma, and red blood cells, respectively.

\section{Microbiology characteristics}

Escherichia coli with extended-spectrum beta-lactamase (ESBL) was isolated from blood and bile cultures in 3 (25\%), and 2 patients (16.6\%), respectively. Other species isolated in bile included Aeromonas hydrophila, Klebsiella pneumonie and Staphylococcus aureus.

\section{Treatment}

Initially all patients received broad spectrum antibiotics, including carbapenems and vancomycin in most cases, as shown in Table 1. Cholecystostomy was performed in 9 patients (75\%): the approach was percutaneous in 8 cases and open in one. Furthermore, 2 patients (16.6\%) underwent laparoscopic cholecystectomy, and one (8.3\%) received only medical treatment. It is worth to mention that 4 of the 5 patients with acalculous cholecystitis were treated with cholecystostomy tube and one of them was treated only with antibioitcs. After four weeks three patients that were initially treated with cholecystostomy underwent interval laparoscopic cholecystectomy, and another patient had the cholecystostomy tube removed, with no complications. One patient still has a cholecystostomy in place.

\section{Outcomes}

Four patients died (33.3\%), three of them had undergone cholecystostomy and the patient that received only medical treatment died too. The cause of death was sepsis with multiorgan failure, one patient had concomitant neutropenic enterocolitis. Three out of 6 patients $(50 \%)$ with acalculous cholecystitis died. 


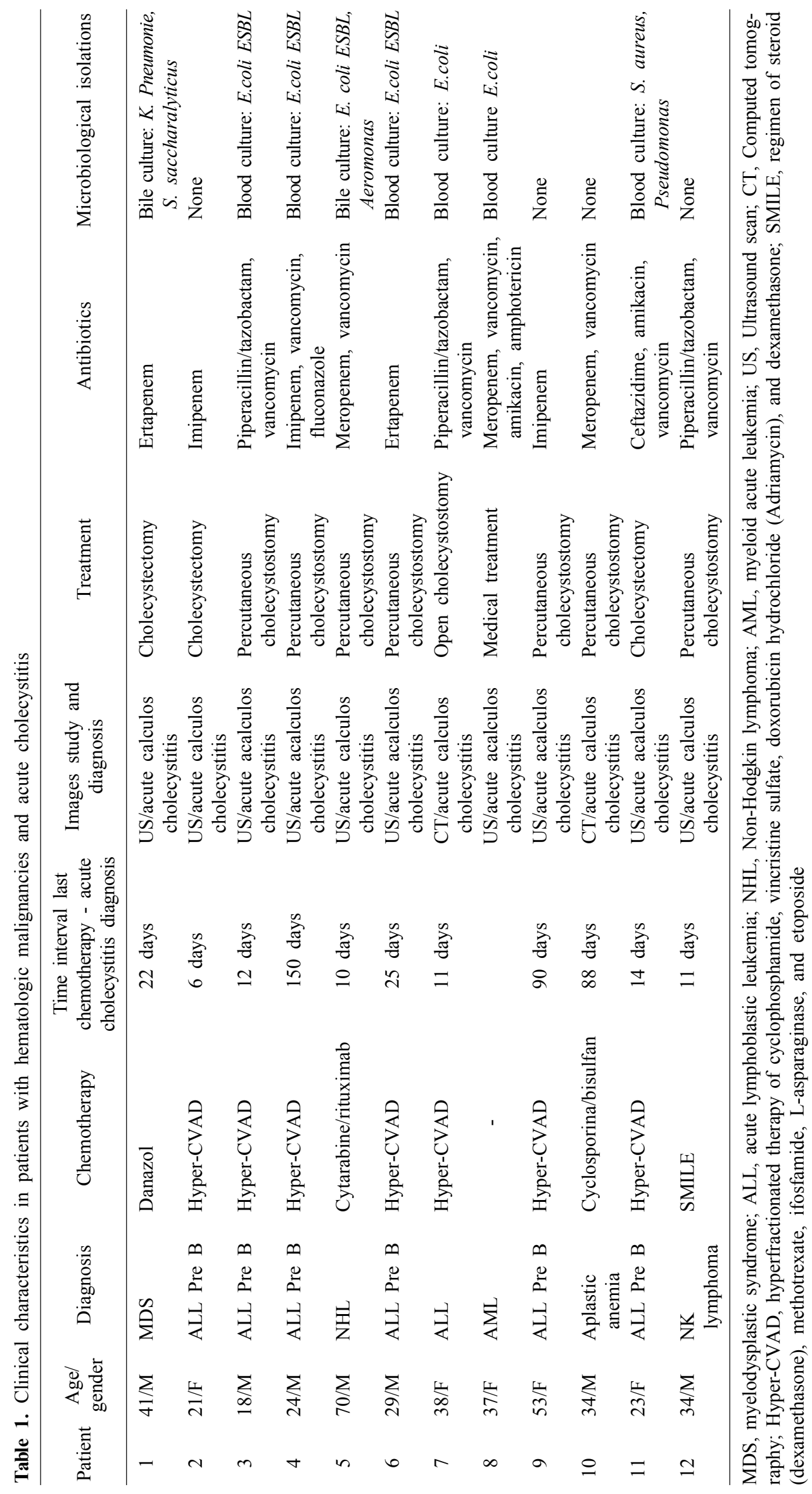


Table 2. Acute cholecystitis diagnosis and grading

\begin{tabular}{|c|c|c|c|c|}
\hline Patient & $\begin{array}{l}\text { Signs of local } \\
\text { inflammation }\end{array}$ & $\begin{array}{l}\text { Signs of systemic } \\
\text { inflammation }\end{array}$ & Image study & Severity criteria \\
\hline 1 & Positive, Murphy & $\begin{array}{l}\text { Fever, tachycardia, } \\
\text { elevated CRP } 5.71\end{array}$ & $\begin{array}{l}\text { US, Gallbladder size: } 10 \times 5.6 \times 5.7 \mathrm{~cm} \text {, } \\
\text { Wall thickness: } 6 \mathrm{~mm} \text {, Gallbladder stones } \\
\text { presence, Pericholecystic fluid presence }\end{array}$ & Platelets $<100,000 / \mathrm{mm}^{3}$ \\
\hline 2 & $\begin{array}{l}\text { Right upper } \\
\text { quadrant pain }\end{array}$ & None & $\begin{array}{l}\text { US, Gallbladder size: } 11.4 \times 4.8 \times 4.2 \mathrm{~cm} \text {, } \\
\text { Wall thickness } 2 \mathrm{~mm} \text {, Gallbladder stone } \\
\text { presence, Pericholecystic fluid absence }\end{array}$ & None \\
\hline 3 & Positive, Murphy & Tachycardia & $\begin{array}{l}\text { US, Gallbladder size: } 12.1 \times 4 \times 4.2 \mathrm{~cm} \text {, } \\
\text { Wall thickness: } 2.9 \mathrm{~mm} \text {, Gallbladder stone } \\
\text { absence, Pericholecystic fluid absence }\end{array}$ & $\begin{array}{l}\text { Platelets }<100,000 / \mathrm{mm}^{3} \\
\text { Creatinine }>2.0 \mathrm{mg} / \mathrm{dl}\end{array}$ \\
\hline 4 & Positive, Murphy & Fever, tachycardia & $\begin{array}{l}\text { US, Gallbladder size: } 10.3 \times 4.8 \times 4.3 \mathrm{~cm} \text {, } \\
\text { Wall thickness: } 8 \mathrm{~mm} \text {, Gallbladder stone } \\
\text { absence, Pericholecystic fluid presence }\end{array}$ & $\begin{array}{l}\text { Platelets }<100,000 / \mathrm{mm}^{3} \\
\text { Hypotension requiring vasopressors }\end{array}$ \\
\hline 5 & $\begin{array}{l}\text { Right upper } \\
\text { quadrant pain }\end{array}$ & $\begin{array}{l}\text { Fever, tachycardia, } \\
\text { elevated CRP } 9.13\end{array}$ & $\begin{array}{l}\text { US, Gallbladder size: } 11.2 \times 4.3 \times 3.1 \mathrm{~cm} \text {, } \\
\text { Wall thickness: } 5.2 \mathrm{~mm} \text {, Gallbladder stone } \\
\text { presence, Pericholecystic fluid presence }\end{array}$ & $\begin{array}{l}\text { Platelets }<100,000 / \mathrm{mm}^{3} \\
\text { Hypotension requiring vasopressors } \\
\text { Creatinine }>2.0 \mathrm{mg} / \mathrm{dl}\end{array}$ \\
\hline 6 & Positive, Murphy & $\begin{array}{l}\text { Fever, tachycardia, } \\
\text { elevated CRP } 28.4\end{array}$ & $\begin{array}{l}\text { US, Gallbladder size: } 13 \times 6.2 \times 4.2 \mathrm{~cm} \text {, } \\
\text { Wall thickness: } 3.2 \mathrm{~mm} \text {, Gallbladder stone } \\
\text { absence, Pericholecystic fluid absence }\end{array}$ & $\begin{array}{l}\text { Platelets }<100,000 / \mathrm{mm}^{3} \\
\text { Hypotension requiring vasopressors } \\
\mathrm{PaO} 2 / \mathrm{FiO} 2 \text { ratio }<300\end{array}$ \\
\hline 7 & None & Fever, tachycardia & $\begin{array}{l}\text { CT, Gallbladder size: } 7.3 \times 4.5 \times 2.7 \mathrm{~cm} \text {, } \\
\text { Wall thickness: } 10 \mathrm{~mm} \text {, Gallbladder stone } \\
\text { presence, Pericholecystic fluid presence }\end{array}$ & $\begin{array}{l}\text { Platelets }<100,000 / \mathrm{mm}^{3} \\
\text { Hypotension requiring vasopressors } \\
\text { Creatinine }>2.0 \mathrm{mg} / \mathrm{dl} \\
\mathrm{PaO} 2 / \mathrm{FiO} 2 \text { ratio }<300\end{array}$ \\
\hline 8 & $\begin{array}{l}\text { Right upper } \\
\text { quadrant pain }\end{array}$ & Fever, tachycardia & $\begin{array}{l}\text { US, Gallbladder size: } 3.13 \times 8.26 \times 3.3 \mathrm{~cm} \text {, } \\
\text { Wall thickness: } 4.3 \mathrm{~mm} \text {, Gallbladder stone } \\
\text { absence, Pericholecystic fluid presence }\end{array}$ & $\begin{array}{l}\text { Platelets }<100,000 / \mathrm{mm}^{3} \\
\text { Hypotension requiring vasopressors } \\
\text { Creatinine }>2.0 \mathrm{mg} / \mathrm{dl} \\
\mathrm{PaO} 2 / \mathrm{FiO} 2 \text { ratio }<300\end{array}$ \\
\hline 9 & Positive, Murphy & Elevated CRP 14 & $\begin{array}{l}\text { US, Gallbladder size: } 11.6 \times 4.3 \times 4.6 \mathrm{~cm} \text {, } \\
\text { Wall thickness: } 2 \mathrm{~mm} \text {, Gallbladder stone } \\
\text { absence, Pericholecystic fluid absence }\end{array}$ & Platelets $<100,000 / \mathrm{mm}^{3}$ \\
\hline 10 & Positive, Murphy & Fever, tachycardia & $\begin{array}{l}\text { US, Gallbladder size: } 8.3 \times 3.5 \times 4 \mathrm{~cm} \text {, } \\
\text { Wall thickness: } 3.3 \mathrm{~mm} \text {, Gallbladder stone } \\
\text { presence, Pericholecystic fluid presence }\end{array}$ & Platelets $<100,000 / \mathrm{mm}^{3}$ \\
\hline 11 & Positive, Murphy & Fever, tachycardia & $\begin{array}{l}\text { CT, Gallbladder size: } 4.4 \times 3.2 \times 2.7 \mathrm{~cm} \text {, } \\
\text { Wall thickness: } 3 \mathrm{~mm} \text {, Gallbladder stone } \\
\text { absence, Pericholecystic fluid presence }\end{array}$ & Platelets $<100,000 / \mathrm{mm}^{3}$ \\
\hline 12 & $\begin{array}{l}\text { Right upper } \\
\text { quadrant pain }\end{array}$ & $\begin{array}{l}\text { Fever, tachycardia, } \\
\text { elevated CRP } 16.3\end{array}$ & $\begin{array}{l}\text { US, Gallbladder size: } 7.4 \times 3.2 \times 2.8 \mathrm{~cm} \text {, } \\
\text { Wall thickness: } 6 \mathrm{~mm} \text {, Gallbladder stone } \\
\text { presence, Pericholecystic fluid presence }\end{array}$ & Platelets $<100,000 / \mathrm{mm}^{3}$ \\
\hline
\end{tabular}

US, Ultrasound; CT, Computed tomography; CRP, C reactive protein

\section{DISCUSSION}

Abdominal pain in patients with neutropenia might require an exhaustive approach due to its broad differential diagnosis and atypical presentation among these patients, ${ }^{12}$ who may not present an inflammatory response. Despite neutropenic enterocolitis being the most common etiology in this scenario, ${ }^{13}$ acute cholecystitis should be considered as a differential diagnosis. ${ }^{14}$ It is thought that the smaller mucosal surface of the gallbladder compared with the colon might explain the low frequency of acute cholecystitis as etiology of abdominal pain in neutropenic patients with fever. ${ }^{1}$ Our study showed a frequency of $0.59 \%$ without male or female predominance, similar to the reported in other series. ${ }^{15}$ Acalculous cholecystitis was documented in $50 \%$ of the cases, compared to $55-65 \%$ in other series. ${ }^{16}$ In non-neutropenic patients acalculous cholecystitis is much less frequent, comprising roughly $5 \%$ of the cases of acute cholecystitis. This may be because patients with neutropenia have several risk factors for this presentation such as bile stasis, prolonged fasting, and increased intraluminal pressure., 
Table 3. Treatment, complications and transfusion requirements

\begin{tabular}{|c|c|c|c|c|c|c|}
\hline Patient & Treatment & Complications & $\begin{array}{l}\text { Clavien } \\
\text { Dindo. }\end{array}$ & Transfusion requirement & $\begin{array}{l}\text { Interval } \\
\text { cholecystectomy }\end{array}$ & Mortality \\
\hline 1 & Cholecystectomy & Acute cholangitis & $\mathrm{IIb}$ & Platelets transfusion $\times 2$ & - & No \\
\hline 2 & Cholecystectomy & None & - & None & - & No \\
\hline 3 & Cholecystostomy & Septic shock & $\mathrm{V}$ & $\begin{array}{l}\text { Platelets transfusion } \times 1 \\
\text { Red blood cells transfusion } \times 2\end{array}$ & No & No \\
\hline 4 & Cholecystostomy & None & & $\begin{array}{l}\text { Platelets transfusion } \times 1 \\
\text { Red blood cells transfusion } \times 1\end{array}$ & No & $\begin{array}{r}\text { Neutropenic } \\
\text { enterocolitis }\end{array}$ \\
\hline 5 & Cholecystostomy & None & - & Red blood cells transfusion $\times 1$ & No & No \\
\hline 6 & Cholecystostomy & None & - & $\begin{array}{l}\text { Platelets transfusion } \times 2 \\
\text { Red blood cells transfusion } \times 1\end{array}$ & $\begin{array}{l}\text { Laparoscopic } \\
\text { cholecystectomy }\end{array}$ & No \\
\hline 7 & Cholecystostomy & $\begin{array}{l}\text { Hepatic subcapsular hem- } \\
\text { atoma }\end{array}$ & I & $\begin{array}{l}\text { Platelets transfusion } \times 1 \\
\text { Red blood cells transfusion } \times 1\end{array}$ & $\begin{array}{l}\text { Open } \\
\text { cholecystectomy }\end{array}$ & No \\
\hline 8 & Antibiotics & Multiorganic failure & $\mathrm{V}$ & Fresh frozen plasma transfusion $\times 4$ & - & Septic shock \\
\hline 9 & Cholecystostomy & None & - & None & $\begin{array}{l}\text { Laparoscopic } \\
\text { cholecystectomy }\end{array}$ & Septic shock \\
\hline 10 & Cholecystostomy & Multiorganic failure & $\mathrm{V}$ & Platelets transfusion $\times 1$ & No & Septic shock \\
\hline 11 & Cholecystectomy & None & - & $\begin{array}{l}\text { Platelets transfusion } \times 1 \\
\text { Red blood cells transfusion } \times 2\end{array}$ & - & No \\
\hline 12 & cholecystostomy & None & - & Platelets transfusion $\times 1$ & $\begin{array}{l}\text { Laparoscopic } \\
\text { cholecystectomy }\end{array}$ & No \\
\hline
\end{tabular}

Treatment decision between surgical cholecystectomy or percutaneous cholecystostomy in these patients is troublesome since most of them fulfill criteria for severe acute cholecystitis and might require the former according to Tokyo recommendations, ${ }^{11}$ however, there is not enough evidence to recommend one procedure over the other in this specific population. All our patients met Tokyo criteria for acute cholecystitis, and 11 patients (91\%) were classified as severe based on hematological failure resulting either from their underlying disease or from chemotherapy induced myelosuppression, but probably not because of severe sepsis, which questions the validity of these criteria in this specific population. As a matter of fact, hematologic failure was the only criteria of severity in 5 of 11 patients. Hematologic disease is an important factor to consider when planning treatment because most patients will need transfusion of blood products prior to any invasive procedure. In our study ten patients $(83.3 \%)$ required blood products including platelets transfusion in 8 patients $(88.8 \%)$, fresh frozen plasma in 1 patient $(11.1 \%)$ and red blood cells transfusion in 1 patients $(11.1 \%)$.

Concerning treatment (Table 3), cholecystostomy was performed in 9 patients (75\%), laparoscopic cholecystectomy in $2(16.6 \%)$, and one patient received only medical treatment. Mortality in our series was $33.3 \%$, which is in line with the $26-48 \%$ reported in previous studies. ${ }^{17}$ Septic shock was the main cause of death. There were no deaths in the laparoscopic cholecystectomy group, while three patients in the cholecystostomy group (37\%), and one in the antibiotic treatment group died. According to these results, surgical cholecystectomy or percutaneous cholecystostomy may be more beneficial than antibiotic treatment alone. Mortality was higher in acalculous presentation when compared to calculous cholecystitis $(50 \%$ versus $16.6 \%$, respectively) probably explained by the fact that the former represents a group of patients with a more severe disease or with a delayed diagnosis.

In conclusion, acute cholecystitis in neutropenic patients is a rare diagnosis, accounting for less than $1 \%$ of the neutropenic fever admissions. Among this group of patients, acalculous cholecystitis is more frequent than in general population. Blood and bile cultures should be obtained so it can help to guide antimicrobial therapy. Since there are no guidelines for acute cholecystitis in neutropenic patients, their treatment should be individualized, for those with acalculous cholecystitis cholecystostomy tube placement is preferred; those presenting with calculous cholecystitis can be treated either with cholecystostomy tube if the patient is unstable or laparoscopic cholecystectomy if the patient's general condition allows it. 


\section{REFERENCES}

1. Gorschlüter M, Mey U, Strehl J, Schepke M, Lamberti C, Sauerbruch T, et al. Cholecystitis in neutropenic patients: retrospective study and systematic review. Leuk Res 2006;30:521528.

2. Büyükaşik Y, Koşar A, Demiroğlu H, Altinok G, Ozcebe OI, Dündar S. Acalculous acute cholecystitis in leukemia. J Clin Gastroenterol 1998;27:146-148.

3. Orlando R 3rd, Gleason E, Drezner AD. Acute acalculous cholecystitis in the critically ill patient. Am J Surg 1983;145:472476.

4. Howard RJ. Acute acalculous cholecystitis. Am J Surg 1981;141: 194-198.

5. Gorschlüter M, Mey U, Strehl J, Schmitz V, Rabe C, Pauls K, et al. Invasive fungal infections in neutropenic enterocolitis: a systematic analysis of pathogens, incidence, treatment and mortality in adult patients. BMC Infect Dis 2006;6:35.

6. Picardi M, Selleri C, Camera A, Catalano L, Rotoli B. Early detection by ultrasound scan of severe post-chemotherapy gut complications in patients with acute leukemia. Haematologica 1999; 84:222-225.

7. Starnes HF Jr, Moore FD Jr, Mentzer S, Osteen RT, Steele GD $\mathrm{Jr}$, Wilson RE. Abdominal pain in neutropenic cancer patients. Cancer 1986;57:616-621.

8. Vaughn EA, Key CR, Sterling WA Jr. Intraabdominal operations in patients with leukemia. Am J Surg 1988;156:51-53.
9. Valent P. Low blood counts: immune mediated, idiopathic, or myelodysplasia. Hematology Am Soc Hematol Educ Program 2012;2012:485-491.

10. Miura F, Takada T, Kawarada Y, Nimura Y, Wada K, Hirota $\mathrm{M}$, et al. Flowcharts for the diagnosis and treatment of acute cholangitis and cholecystitis: Tokyo guidelines. J Hepatobiliary Pancreat Surg 2007;14:27-34.

11. Miura F, Takada T, Strasberg SM, Solomkin JS, Pitt HA, Gouma DJ, et al. TG13 flowchart for the management of acute cholangitis and cholecystitis. J Hepatobiliary Pancreat Sci 2013;20: 47-54.

12. Trowbridge RL, Rutkowski NK, Shojania KG. Does this patient have acute cholecystitis? JAMA 2003;289:80-86.

13. Wade DS, Nava HR, Douglass HO Jr. Neutropenic enterocolitis. Clinical diagnosis and treatment. Cancer 1992;69:17-23.

14. Kuttah L, Weber F, Creger RJ, Fox RM, Cooper BW, Jacobs $\mathrm{G}$, et al. Acute cholecystitis after autologous bone marrow transplantation for acute myeloid leukemia. Ann Oncol 1995;6:302304.

15. Wasserheit C, Acaba L, Gulati S. Abnormal liver function in patients undergoing autologous bone marrow transplantation for hematological malignancies. Cancer Invest 1995;13:347-354.

16. Teefey SA, Kimmey MB, Bigler SA, Trowers EA, Sillery JK. Gallbladder wall thickening: an in vitro sonographic study with histologic correlation. Acad Radiol 1994;1:121-127.

17. Storti S, Marra R, Pagano L, Sica S, Borzone, Cagossi M, et al. Emergency abdominal surgery in patients with acute leukemia and lymphoma. Ital J Surg Sci 1988;18:361-363. 